\title{
Teresa of Avila and Jonathan Edwards on Prayer and Spirituality
}

\author{
Jonathan Liem Yoe Gie $\mathbb{C}$ \\ Gereja Kebangunan Kalam Allah Indonesia Tenggilis Mejoyo, Indonesia \\ liem.jonathan88@gmail.com
}

\begin{abstract}
Contemplative prayer has been a major source of contention in evangelical spirituality. Contemplative prayer is frequently mentioned as one apparent spiritual activity that is foreign to the scripture and Christian worldview and more resembling the New Age Movement and pantheistic Eastern religion by people who are skeptical of the mystical Christian tradition. This article will examine Teresa of Avila's thought on mystical prayer, which is sometimes misinterpreted as a notion incompatible with evangelical theology of prayer. Hence, Teresa's ideas of mystical prayer will be examined and compared with Jonathan Edwards' concepts of prayer, which is considered to reflect evangelical theology of prayer. The comparison suggests that the contemplative, mystical prayer of Teresa is compatible with evangelical theology of prayer in its progress and purpose. Teresa and Edwards both understood prayer as an experience and progress that leads to the complete union with God, mediated by Christ and his words in scripture. This spiritual union with God will transform the devoted one with tremendous passion and strength to love and help others in their struggle and suffering. This study of Teresa's thought of mystical prayer is expected to reinvigorate evangelical theology and praxis of prayer by learning from the rich spirituality of the Christian mystical tradition.
\end{abstract}

\section{Research Highlights}

- This research compares Teresa of Avila's and Jonathan Edwards's perspectives on the direction and purpose of prayer and spirituality.

- The comparison findings reveal that Teresa of Avila's concept of mystical prayer is compatible with the evangelical theology of prayer and, even more, may enrich its praxis.

\section{Article history}

Submitted 9 December 2020

Revised 16 May 2021

Accepted 23 June 2021

\section{Keywords}

Teresa of Avila; Jonathan

Edwards; mystical prayer; mystical theology;

contemplative prayer; receptive prayer; spirituality

(C) 2021 by author.

Licensee Veritas: Jurnal

Teologi dan Pelayanan.

This article is licensed under the term of the Creative

Commons Attribution-

NonCommercial-ShareAlike

4.0 International

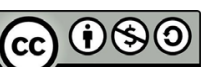




\title{
Pemikiran Teresa dari Avila and Jonathan Edwards tentang Doa dan Spiritualitas
}

\author{
Jonathan Liem Yoe Gie \\ Gereja Kebangunan Kalam Allah Indonesia Tenggilis Mejoyo, Indonesia \\ liem.jonathan88@gmail.com
}

\begin{abstract}
Abstrak: Doa kontemplatif telah menjadi sumber perdebatan dalam spiritualitas injili. Bagi mereka yang skeptis terhadap tradisi mistik Kristen, doa kontemplatif dinilai tidak sesuai dengan ajaran Alkitab dan wawasan dunia Kristen serta lebih cocok disandingkan dengan Gerakan Zaman Baru dan agama-agama Timur yang panteistik. Artikel ini akan mengulas teologi doa mistik Teresa dari Avila yang sering kali disalahmengerti sebagai sebuah konsep doa yang tidak sesuai dengan nilai-nilai teologi injili. Karena itu, konsep doa Teresa akan dikaji dan dibandingkan dengan perspektif teologi doa Jonathan Edwards, yang dapat dikatakan mewakili teologi injili. Dari hasil perbandingan didapati bahwa teologi doa Teresa dan Edwards memiliki kesamaan arah dan tujuan. Baik Teresa maupun Edward melihat doa sebagai proses dan pengalaman menuju kepenuhan dari kesatuan jiwa seseorang dengan Allah, yang diperantarai oleh Kristus dan firman-Nya. Kesatuan rohani dengan Allah tersebut akan menghasilkan transformasi yang menggerakkan sang pendoa dengan hasrat dan potensi yang besar untuk mengasihi dan melayani sesama di dalam pergumulan dan penderitaan mereka. Kajian terhadap teologi doa mistik Teresa ini diharapkan dapat memperkaya teologi injili dengan belajar dari kekayaan spiritualitas tradisi mistik Kristen.
\end{abstract}

Kata-kata kunci: Teresa dari Avila; Jonathan Edwards; doa mistik; teologi mistik; doa kontemplatif; doa reseptif; spiritualitas

\section{PENDAHULUAN}

Di dalam Kekristenan, secara garis besar terdapat dua bentuk pembagian spiritualitas yang mayoritas disetujui oleh para teolog. Bentuk spiritualitas yang pertama disebut tradisi profetik, yang lebih menekankan sikap aktif di dalam pendekatannya. Bentuk tradisi spiritualitas ini menekankan pencurahan isi hati kepada Tuhan untuk membuat Tuhan semakin mengenal kebutuhan dan keinginan pribadi sang pendoa, dan kebergantungan sebagai respons dari sang pendoa. ${ }^{1}$ Luther dan Calvin setuju bahwa di dalam doa sebagai

${ }^{1}$ Donald G. Bloesch, "Prayer and Mysticism (2): Divergent Views on Prayer," Reformed Journal 26, no. 4 (April 1976): 22-25. permohonan ini terdapat juga doa yang berbentuk ucapan syukur atau pengakuan dosa. $^{2}$

Tradisi ini memahami bahwa mungkin saja ada keheningan di dalam doa, namun keheningan itu hanyalah sebagai suatu persiapan untuk doa yang sesungguhnya. Karena itu, tradisi ini lebih sering memakai bentuk doa vokal, di mana sang pendoa mengeluarkan kata-kata secara verbal untuk mengekspresikan doanya. Kata-kata di dalam doa kepada Tuhan ini dideskripsikan oleh Kenneth Boa sebagai "personal communion and dialogue 
with the living God." 3 Semangat teologi Reformed juga mengatakan bahwa kata-kata permohonan yang dipanjatkan dalam doa merupakan hal yang diinginkan Tuhan. Hal ini juga mengimplikasikan bahwa kata-kata bukanlah bentuk inferior dari komunikasi dan perlu ditingkatkan melalui "deep communion," melainkan seharusnya menjadi suatu media untuk mencapai suatu relasi yang paling intim antara Tuhan dengan anak-anakNya. ${ }^{4}$ Tradisi ini juga tidak mengenal adanya pengulangan kata-kata ataupun pengucapan "mantra" seperti pada doa yang primitif dan doa ritual. ${ }^{5}$ Tradisi profetik juga lebih menekankan pertobatan, jaminan, pelayanan, kebangkitan iman, dan ketaatan, karena menurut tradisi ini, iman Kristen berbicara mengenai apa yang kita lakukan untuk memuliakan Tuhan dengan cara melayani orang lain. ${ }^{6}$

Bentuk spiritualitas yang kedua adalah tradisi mistik, yang lebih menekankan sikap reseptif. Berbeda dengan tradisi profetik, tradisi mistik lebih menekankan kesatuan dengan Tuhan sebagai cara untuk memuliakan Tuhan. Menurut tradisi ini, doa di dalam kekristenan seharusnya dilihat sebagai suatu perjumpaan dengan pribadi ilahi, yakni Yesus Kristus. Tujuan dari doa ini adalah mengalami kesatuan dan kedekatan yang semakin mendalam dengan Tuhan melalui pengalaman nyata terhadap kehadiran ilahi. ${ }^{7}$ Karena itu, bentukbentuk praktis kehidupan spiritual dari tradisi ini adalah bagaimana berpartisipasi di dalam Allah Trinitas melalui Kristus. ${ }^{8}$ M.M. Poloma dan M.T. Lee mengatakan, "Prayer is more than an activity; it involves a relationship with

${ }^{3}$ Kenneth Boa, Conformed to His Image (Grand Rapids: Zondervan, 2001), 171.

${ }^{4}$ Peter J. Jensen, "Prayer in Reformed Perspective," Reformed Theological Review 44, no. 3 (1985): 65-73.

${ }_{5}^{5}$ Donald G. Bloesch, 1976, "Prayer and Mysticism (3) Towards Renewed Evangelical Prayer," Reformed Journal 26, no. 5 (Mei-Juni 1976): 20-22.

${ }^{6}$ Donald G, Bloesch, "Prayer and Mysticism (1) Two Types of Spirituality," Reformed Journal 26, no. 3 (Maret 1976): 23-26. the divine that incluedes two other dimensions that we call "prophetic dialogue" and "divine communion." 9 Menurut mereka, selain memang ada dimensi aktif yang melibatkan aktivitas manusia di dalam doa, ada pula dimensi yang lain yang disebut dimensi reseptif. Dimensi yang tidak terdapat di dalam doa menurut tradisi profetik inilah yang dapat membawa doa bukan sekadar menjadi percakapan seorang diri, melainkan menjadi dialog dengan pribadi ilahi di dalam kesatuan secara mistis.

Tidak hanya itu, tradisi ini juga menekankan bahwa kontemplasi yang dilakukan menjadi sarana terjadinya transformasi. Melalui transformasi itu, seorang pendoa secara mendasar akan mengalami kesatuan hati dan pikiran dengan Sang Pencipta. Kesatuan ini diikuti oleh perasaan sukacita, damai, bahagia yang membuat sang pendoa rindu mengingini hanya apa yang Tuhan inginkan dan melakukan hanya apa yang Tuhan kehendaki. J. Owen, seorang teolog Puritan menyarankan orang Kristen untuk melakukan perenungan akan kekudusan Tuhan, sehingga mereka dapat mencapai keserupaan dengan Kristus, karena pikiran kita akan diubah menjadi seperti gambaran yang kita kontemplasikan. ${ }^{10}$

Kedua arus tradisi spiritualitas ini selalu mengalami ketegangan di dalam spiritualitas Kristen. Ada teolog-teolog yang berpendapat bahwa bentuk doa yang aktif di dalam tradisi profetik merupakan doa yang lebih setia

\footnotetext{
${ }^{7}$ Jim Wilhoit, "Contemplative and Centering Prayer," Journal of Spiritual Formation and Soul Care 7, no. 1 (2014): 107-117, https://doi.org/10.1177/193979091400700110.

${ }^{8}$ Gustave Reininger, "Centering Prayer and the Christian Contemplative Tradition," Sewanee Theological Review 40, no. 1 (1996): 34.

${ }^{9}$ Margaret M. Poloma dan Matthew T. Lee, "From Prayer Activities to Receptive Prayer: Godly Love and the Knowledge that Surpasses Understanding," Journal of Psychology and Theology 39, no. 2 (Juni 2011): 146. https://doi.org/10.1177/009164711103900205.

${ }^{10}$ Bloesch, "Prayer and Mysticism (3)," 2.
} 
kepada doktrin-doktrin Kristen. ${ }^{11}$ Di sisi lain, ada teolog-teolog yang mengatakan bahwa doa yang bersifat reseptif di dalam tradisi mistik ini merupakan gambaran yang lebih utuh terhadap apa yang seharusnya orang lakukan di dalam doa. ${ }^{12}$

Topik mengenai doa mistik telah menjadi suatu kontroversi yang cukup besar, terkhusus di antara kalangan injili. Tidak jarang terdapat kritik-kritik terhadap praktik maupun konsep doa mistik yang diberikan oleh teologteolog injili yang mendalami bidang spiritualitas. Beberapa kritik yang sering kali muncul adalah bahwa tradisi doa mistik ini berakar pada spiritualitas agama ataupun kepercayaan lain yang tidak sesuai dengan kebenaran firman Tuhan (bersifat panteistik ataupun panenteistik), seperti agama-agama timur maupun pengaruh dari Gerakan Zaman Baru. ${ }^{13}$ Salah satu contohnya adalah kritik yang diberikan oleh Ray Yungen di dalam bukunya A Time of Departing, di mana ia percaya bahwa doa kontemplatif dan panenteisme adalah dua hal yang berjalan bersama seperti tangan di dalam sarung tangan sehingga mendukung doa kontemplasi berarti mendukung juga panenteisme. ${ }^{14} \mathrm{Di}$ dalam argumennya, Bloesch memaparkan bahwa begitu banyak teolog mistik yang tampaknya melakukan pendekatan panteistik di dalam doanya, seperti Teresa dari Avila yang berkata, "there is nothing in me that is not God: my 'me' is God" atau Catherine dari Genoa yang berkata, "my being is God, not by simple participation but by a true transformation of my being." 15 Dugaan pendekatan panteistik ini disebabkan karena

\footnotetext{
${ }^{11}$ Evan B. Howard, "Is Thoughtless Prayer Really Christian? A Biblical/Evangelical Response to Evagrius of Pontus," Journal of Spiritual Formation and Soul Care 7, no. 1 (Mei 2014): 118-139, https://doi.org/10.1177/19397909 1400700111.

${ }^{12}$ Poloma dan Lee, "From Prayer Activities to Receptive Prayer," 143-154.

${ }^{13}$ John H. Coe, "The Controversy Over Contemplation and Contemplative Prayer: A Historical, Theological, and Biblical Resolution," Journal of Spiritual Formation and Soul Care 7, no. 1 (Mei 2014): 140-153, https://doi.org/ 10.1177/193979091400700112.
}

tradisi mistik didasari oleh pemikiran neoplatonisme, di mana fokus dari manusia adalah peninggian diri secara spiritual untuk mencapai titik ilahi melalui usaha manusia sebagai suatu nilai kebaikan. Karena pandangan seperti ini, banyak tradisi dari dimensi doa mistik telah ditinggalkan dan kurang dikembangkan, terkhusus oleh kalangan teolog injili profetik. Oleh karena itu diperlukan adanya dialog terhadap tradisi doa mistik ini, sebagai sebuah keterbukaan dari teologi injili profetik terhadap teologi mistik.

Mengingat kontroversi dan kritik di atas, penelitian ini bertujuan untuk memberikan sebuah penjabaran mengenai doa mistik, terkhusus pada salah satu tokoh yang memiliki sumbangsih yang besar dan representatif terhadap konsep doa mistik, yakni Teresa dari Avila (1515-1582). ${ }^{16}$ Ia menuliskan banyak buku mengenai konsep doa, seperti The Book of Her Life (1565), The Way of Perfection (1566), The Foundation (1573), dan karya agungnya The Interior Castle (1577). ${ }^{17}$ Karyakarya dari Teresa ini menggambarkan konsep doa dari tradisi mistik pada abad ke-16.

Di dalam perkembangannya, definisi dari mistisisme telah mengalami perkembangan dan perubahan. Peter Tyler memberikan gambaran mengenai pergeseran definisi yang terjadi mengenai mistisisme Kristen yang berkembang di Spanyol pada abad ke-17, menjadi mistisisme modern yang berkembang mulai abad ke-18 dan ke-19. ${ }^{18}$ Hal ini menyebabkan terjadinya bias di dalam pemahaman yang benar terhadap mistisisme Kristen yang

\footnotetext{
${ }^{14}$ Ray Yungen, A Time of Departing: How Ancient Mystical Practices are Uniting Christians with the World's Religions, ed. ke-2 (Eureka: Lighthouse Trails, 2006), 72.

${ }^{15}$ Bloesch, "Prayer and Mysticism (1)," 3.

${ }^{16}$ Teresa of Avila, The Interior Castle, terj. Kieran Kavanaugh dan Otilio Rodriguez (New York: Paulist, 1979), 3-4.

${ }^{17}$ Ibid., 11-12.

${ }^{18}$ Peter Tyler, The Return to the Mystical: Ludwig Wittgenstein, Teresa of Avila and the Christian Mystical Tradition (London: Continuum, 2011), 1.
} 
dibawa oleh Teresa dari Avila, sehingga teolog injili memberikan batasan yang kuat terhadap spiritualitas Teresa. ${ }^{19}$ Abad ke-17 merupakan masa kejayaan teologi mistik, yakni masa munculnya banyak teolog mistik seperti John of the Cross, John dari Avila maupun Teresa dari Avila. ${ }^{20}$ Definisi awal dari mistisisme yang dikembangkan pada abad ke-17 ini merujuk kepada tradisi apopatik dari Pseudo-Dionysius. ${ }^{21}$ Karya-karya yang termasuk di dalam Dionysian Corpus inilah yang sebenarnya menjadi kunci untuk memahami theologia mystica yang menjadi akar dari teologi mistik pada abad ke-17, termasuk di antaranya teologi mistik Teresa dari Avila. ${ }^{22}$

Berbeda dengan pemahaman di atas, definisi mistisisme modern yang berkembang pada abad ke-19 memberikan gambaran yang lain. Definisi mistisisme dari abad ke-17 telah mengalami pergeseran makna menjadi lebih luas, hingga hasilnya pada tahun 1858 , dalam Encyclopaedia Britannica (edisi ke-8), dijelaskan bahwa mistisisme adalah bentuk pengalaman religius yang memiliki keselarasan karakteristik dengan ekspresi Bhagavat-Gita dari Hindu ataupun tulisan dari Emmanuel Swedenborg. ${ }^{23}$ Pergeseran definisi mistisisme seperti ini yang dapat menimbulkan bias di

${ }^{19}$ Donald S. Whitney mengecam konsep doa dan spiritualitas Teresa dari Avila sebagai sebuah doa yang tidak sesuai dengan tradisi injili Reformed dan seharusnya tidak diakui di dalam tradisi injili Reformed. Lihat Donald S. Whitney, "Defining The Boundaries of Evangelical Spirituality" (makalah yang disajikan pada pertemuan tahunan ke-53 Evangelical Theological Society, 15 November 2001).

${ }^{20}$ Tyler, The Return to the Mystical, 4.

${ }^{21}$ Ibid., 5.

${ }^{22}$ Dionysian Corpus merupakan kumpulan dari karyakarya Pseudo-Dionysius dalam bahasa Latin seperti Mystical Theology, Celestial Hierarchy, Ecclesiastical Hierarchy dan Divine Names. Karya-karya ini masuk di dalam tradisi gereja barat pada tahun 872 ketika Michael the Stammerer memberikannya pada Louis the Pious. Louis memberikannya pada Hilduin, kepala biara dari St. Denis di Paris untuk diterjemahkan dalam bahasa Latin. Karya Dionysian ini mengalami kebangkitan pada abad ke-12 pada saat karya-karya ini dipelajari secara masif oleh biara-biara di St. Denis, hingga mengalami kemunduran oleh karena revolusi Perancis (ibid., 66, 69-70). dalam pemahaman yang benar mengenai mistisisme Kristen. ${ }^{24}$ Tidak jarang, doa-doa di dalam teologi mistik pada zaman ini sering kali disalahpahami sebagai suatu bentuk pengalaman religius yang sama dengan bentukbentuk mistisisme modern, namun sebenarnya tidak menggambarkan mistisisme Kristen abad ke-17. ${ }^{25}$

\section{METODE PENELITIAN}

Metode penelitian yang penulis gunakan adalah studi kepustakaan terhadap sumbersumber tradisi teologi dan doa mistik. Untuk mempelajari lebih lanjut mengenai teologi mistik dan doa mistik pada abad ke-17, penulis akan memaparkan pemikiran Teresa dari Avila, sebagai salah satu contoh teolog mistik yang berkarya pada zaman tersebut. ${ }^{26}$ Konsep Doa Teresa dari Avila ini akan ditinjau dari sudut pandang konsep doa injili Reformed, yaitu konsep doa dari Jonathan Edward. Ia adalah seorang teolog injili Reformed yang memberikan karya-karya pemikiran rasional terhadap pembacaan Alkitab. Namun demikian, Edward juga menghasilkan karya-karya spiritualitas yang berharga bagi kaum injili. ${ }^{27}$

${ }^{23}$ Encyclopaedia Britannica, ed. ke-8 (1857), s.v. "mysticism."

${ }^{24}$ Howard, "Is Thoughtless Prayer Really Christian," 1. Di dalam artikel ini dijelaskan beberapa tuduhan yang sering kali diberikan kepada penganut teologi mistik, di mana bentuk doa mistik memiliki kemiripan dengan bentuk-bentuk doa dari mistik agama timur, gerakan zaman baru, maupun bentuk mistik lain.

${ }^{25}$ Tyler, The Return to The Mystical, 7. Coe juga setuju akan adanya kesalahpahaman mengenai mistisisme ini, yakni bahwa banyak teolog masa kini yang tidak memahami dengan baik mistisisme Kristen, yang sebenarnya berakar pada abad ke-16, namun mereka menyamakannya dengan mistisisme yang tidak biblikal (Coe, "The Controversy over Contemplation," 4).

${ }^{26}$ Douglas R. Groothuis dan Sarah C. Geis, "Examining Contemplative Prayer," Bibliotheca Sacra 172, no. 685 (2015): 12-23. Groothuis juga mengatakan bahwa pemahaman mengenai doa kontemplatif atau doa mistik yang berkembang pada zaman ini mengakar pada tradisi mistik dari Teresa dari Avila.

${ }^{27} J o h n$ D. Hannah, "Jonathan Edwards's Thoughts on Prayer,” Bibliotheca Sacra 173, no. 689 (2016): 82. 


\section{HASIL DAN PEMBAHASAN}

Teresa dari Avila lahir di kota Castilia di Spanyol bagian tengah pada tahun $1515 .{ }^{28}$ Tidaklah mudah untuk menyimpulkan keadaan latar belakang kehidupan di Eropa (terkhusus di Spanyol) pada zaman itu. ${ }^{29}$ Pada masa itu terjadi pergolakan di Eropa di dalam hal politik dan budaya yang disebabkan berakhirnya zaman pertengahan dan lahirnya zaman modern. Tidak hanya itu, terjadi banyak konflik karena adanya perjumpaan Kekristenan dengan budaya, agama dan dunia lain yang ada di sekitar Eropa. ${ }^{30}$ Masalah tabrakan budaya ini menjadi isu pelik yang ditanggapi secara serius oleh para pemikir dan teolog pada zaman itu. Secara khusus, Spanyol merupakan titik krusial di dalam pergerakan sejarah yang penting ini. Di masa seperti inilah, Teresa dari Avila lahir ke dunia.

Teresa dari Avila juga memiliki garis keturunan keluarga yang berpengaruh bagi teologinya. Ayahnya, Alfonso Sanches de Cepeda, berasal dari keluarga Castilian yang sangat terkenal dengan kemurnian iman dan moralnya. ${ }^{31}$ Ibunya yang pertama, Agnes de Cepeda juga termasuk di dalam garis keturunan kerajaan, yakni percabangan dari keluarga Tordesillas yang dihormati karena kebangsawanannya. Ibunya ini memiliki dua anak dari Alfonso. ${ }^{32}$ Setelah ibu pertama Teresa meninggal dunia, ayahnya menikah kembali dengan Dona Beatriz de Ahumada-ibu kandung Teresa-

\footnotetext{
${ }^{28}$ Alice Lady Lovat, The Life of Saint Teresa (London: Herbert \& Daniel, 1912), 1.

${ }^{29}$ Friedrich Heer, Europaische Geistesgeschichte, ed. Johanna Heer dan Sigurd Paul Scheichl (Wien: Böhlau Verlag, 2004), 280-331.

${ }^{30}$ Raimundo Panikkar, "Preface," dalam The Interior Castle, oleh Teresa of Avila, terj. Kieran Kavanaugh dan Otilio Rodriguez (New York: Paulist, 1979), xiii.

${ }^{31}$ Lovat, The Life of Saint Teresa, 1.

${ }^{32}$ Teresa of Avila, The Interior Castle, 1.

${ }^{33}$ Ibid., 2. Meskipun ia menyandang gelar yang begitu terhormat di dalam silsilah keluarganya, ia berkata, "As we are all made of the same clay, to dispute on nobility of birth is the same as to wrangle about wether one kind of clay or another was best fitted for making bricks or potsherds; ... For my part, I am satisfied with being a daughter of the Chuch. A
}

yang mengasihi semua anak-anaknya dan juga berpengaruh besar terhadap pendidikan mereka. Beatriz berperan penting dalam mengajar Teresa banyak hal mengenai kehidupan doa. Pada umur 33 tahun, Beatriz meninggal dunia. Karena adat di Spanyol, ia tidak menyandang nama ayahnya, melainkan ibunya, yakni Teresa de Ahumada, hingga ia mengganti namanya menjadi Teresa of Jesus. ${ }^{33}$

Dari keluarganya inilah, Teresa mendapat banyak keteladanan, seperti kedisiplinan untuk membaca buku-buku dan belas kasihan terhadap sesama. Ia berkata, "My father was very much given to the reading of good books; and so he had them in Spanish that his children might read them." ${ }^{34}$ Ia juga merasa bersyukur bahwa ia dapat melihat kasih yang begitu besar dari orang tuanya terhadap orang-orang miskin, orang sakit dan juga pada para budak. Latar belakang keluarga yang seperti inilah yang membuat Teresa dapat membangun teologi incarnationalism, yakni sebuah harapan bahwa sebuah komunitas dapat menyatakan kerendahan hati, kasih, dan misi dari Yesus yang telah berinkarnasi. ${ }^{35}$

Pada umur 21 tahun, Teresa memasuki kehidupan yang religius dan menjadi biarawan Karmelit di Avila. Ordo Karmelit ini memberikan banyak sumbangsih bagi dunia Eropa pada abad ke-16 yang saat itu sedang meng-

venial sin would be greater cause of humiliation to me than that my origin was an ignoble one" (ibid., 3).

${ }^{34}$ Ibid., 6. Ayah Teresa juga secara eksplisit dikatakan memberikan banyak arahan kepada anak-anaknya untuk membaca buku-buku favorit yang ia pernah baca, termasuk di antaranya Alkitab (ibid., 7, 17).

${ }^{35}$ Julia Gatta, "Mysticism and Incarnation," Sewanee Theological Review 36, no. 2 (1993): 261. Karena Teresa lahir di keluarga yang kaya dan terhormat sebagai minoritas, ditambah pemahamannya akan bagaimana Tuhan menanggalkan segala kemuliaan-Nya di dalam inkarnasi, ia tidak memegang obsesi komunitasnya yang menjunjung tinggi kehormatan mereka sebagai bangsawan, melainkan justru menekankan kasih dan kepedulian terhadap rakyat jelata. 
alami krisis di dalam banyak aspek kehidupan. ${ }^{36}$ Ordo ini berusaha menjawab kebutuhan zaman itu melalui satu hal, yakni kekudusan. Konsep kekudusan yang dikejar oleh biarawan Karmelit ini berakhir pada kekudusan itu sendiri (end in itself), di mana kekudusan ini bertujuan membawa dunia kepada keadaan kerajaan Allah yang melampaui dunia yang fana. ${ }^{37}$ Di dalam mengejar kekudusan itu, para biarawan Karmelit melakukan praktik doa secara pribadi yang dilakukan di dalam komunitas. Bagi mereka, komunitas yang hidup dapat menunjang, mendidik, dan memurnikan kontemplasi dari setiap individu. ${ }^{38}$

Di dalam pengembangannya, biarawan Karmelit ini memberikan dampak secara sosial yang sangat besar bagi conversos (orang-orang Yahudi dan Muslim yang bertobat), dengan cara menolong mereka dari tekanan pihak keluarga atau masyarakat yang menyiksa mereka karena pertobatan yang mereka lakukan. ${ }^{39}$ Keadaan seperti inilah yang menjadi latar belakang dari kisah Teresa dari Avila dan doa dalam teologi mistik, yakni pergerakan yang berasal dari sebuah kota kecil, dimulai dari hidup, hati, dan pikiran beberapa orang di Avila, namun dapat berpengaruh terhadap konflik dunia Eropa di masa pergerakan historis yang masif.

\section{Teologi Spiritualitas Mistik Teresa dari Avila}

Raimundo Panikkar mencoba menyimpulkan teologi mistik dari Teresa sebagai berikut: "The aim and end of human life is Union with

\footnotetext{
${ }^{36}$ Panikkar, "Preface," The Interior Castle, xix. Tujuan dari Ordo Karmelit adalah untuk memimpin anggotanya untuk dapat memiliki kehidupan yang kontemplatif melalui bentuk disiplin doa yang panjang, diawali dengan pengosongan diri (detachment) dan penebusan dosa (penance).

${ }^{37}$ Ibid. Namun demikian, konsep kekudusan yang ditawarkan oleh Ordo Karmelit bukanlah kekudusan yang berfokus pada keegoisan perubahan diri sendiri, maupun kekudusan pribadi yang individualistik, ataupun kekudusan yang hanya berfokus kepada keselamatan diri sendiri.

${ }^{38}$ Gatta, "Mysticism and Incarnation," 261.
}

God, it is the transformation of our being and its divinization." ${ }^{40}$ Bagi Teresa, kebajikan dari jiwa bukanlah terletak dari bagaimana seseorang berpikir, namun dari bagaimana seseorang dapat mengasihi. ${ }^{41}$ Kasih ini didapatkan dengan cara melakukan kehendak Allah sekalipun harus mengalami penderitaan. Terkadang, demi melakukan kehendak Allah, penderitaan itu dapat meningkat. Inilah tujuan kesatuan dengan Allah; yakni kehendak seseorang bersatu di dalam kehendak Allah yang akan membawanya kepada ketaatan pada Allah. ${ }^{42}$ Kesatuan dengan Allah ini dimediasi hanya di dalam Kristus. Kristus menjadi jalan bagi manusia untuk memiliki persahabatan dengan Allah di dalam doa. Yesus adalah penyebab manusia dapat memanggil Allah sebagai Bapa. Yesus juga berperan sebagai Guru yang mengajar manusia untuk dapat datang kepada Allah. ${ }^{43}$

Bagi Teresa, ekaristi menunjukkan keinginan Allah untuk dapat dihampiri oleh ciptaanNya, dan kerendahan hati Allah agar umatNya dapat datang kepada-Nya. Melalui pemecahan tubuh Yesus di dalam setiap ekaristi, manusia mampu berjumpa dengan Allah. ${ }^{44}$ Bagi Teresa, inilah yang menjadi tujuan orang percaya, yakni memiliki kesempatan untuk memasuki kehidupan ilahi melalui penyerahan diri dan kontemplasi terhadap kerendahan hati Allah dan kebutuhan akan Kristus.

\section{Konsep Doa Mistik Teresa dari Avila}

Secara sederhana, Teresa mendefinisikan doa sebagai sebuah percakapan yang intim antara

\footnotetext{
${ }^{39}$ Cristóbal Serrán-Pagán y Fuentes, "The Active Life and the Contemplative Life in St. John of the Cross: The Mixed Life in the Teresian Carmelite Tradition," Religions 11, no. 10 (2020): 509, https://doi.org/10.3390/rel11100509.

${ }^{40}$ Panikkar, "Preface," The Interior Castle, xvi.

${ }^{41}$ Teresa of Avila, The Spirit of S. Teresa (London: Levey and Co., 1866), 53.

${ }^{42}$ Ibid., 53-54, 57.

${ }^{43}$ Kieran Kavanaugh, "Introduction," dalam The Interior Castle, oleh Teresa of Avila (New York: Paulist, 1979), 13.

${ }^{44}$ Gatta, "Mysticism and Incarnation," 261-263.
} 
dua sahabat, yakni sebuah waktu pribadi dengan Tuhan di mana kita mengerti bahwa Ia mengasihi kita. ${ }^{45}$ Sebagai seseorang yang sangat kuat berpengaruh terhadap teologi mistik, Teresa juga memiliki latar belakang teologi dalam hal konsep keberdosaan dan anugerah Allah yang didasari oleh pembacaannya terhadap The Confession dari Agustinus. ${ }^{46}$ Selain masa remajanya dilalui dengan mengecap pendidikan di sekolah yang dikelola oleh biarawati Augustinian dari Nuestra Señora de Gracia di Avila, ia juga membaca The Confession pada tahun 1554 ketika pertama kalinya buku itu diterjemahkan ke dalam bahasa Spanyol. ${ }^{47}$

Penerimaannya atas teks klasik ini datang pada momen penting dalam hidupnya ketika, setelah dua puluh tahun sebagai biarawati Karmelit di Biara Encarnación di Avila, dia melihat perubahan dalam doanya di hadapan gambar Kristus yang menderita. Karena itu, bagi Teresa, perjumpaan dengan Allah hanya dapat dimediasi oleh Yesus Kristus, yang membimbing manusia kepada Allah di dalam penderitaan Kristus. Baginya, tanpa Yesus sebagai Pemimpin, proses kontemplasi tidak akan mencapai tujuannya. Karena itu, Yesus menjadi pusat di dalam doa, dan setiap meditasi yang dilakukan di dalam doa harus difokuskan kepada Yesus. ${ }^{48}$

Selain itu, pembacaan Teresa terhadap The Confession juga mempengaruhi pendekatannya terhadap firman Tuhan. Teresa menemukan juga tole lege dari pengalaman Agustinus,

\footnotetext{
${ }^{45}$ Kavanaugh, "Introduction," 13.

${ }^{46}$ Donald Christopher Nugent, "What Has Wittenberg to Do With Avila: Martin Luther and Saint Teresa," Journal Of Ecumenical Studies 23, no. 4 (September 1986): 651.

${ }^{47}$ Kevin M. DePrinzio, "Your Word Pierced My Heart, and I Fell in Love: Teresa of Avila's Reading of Augustine of Hippo's Confessions" (disertasi, Catholic University of America, 2017), 2. DePrinzio menuliskan bahwa, "Although the connection between these two figures may not be an obvious one initially, anyone familiar with Teresa's writings could easily recall her fondness for Augustine and how she came to endear herself to him."
}

sehingga pembacaannya terhadap firman Tuhan pun mempengaruhi teologi mistiknya. ${ }^{49}$ Untuk mendalami konsep doa dari Teresa, dari banyak karya yang ditulis oleh Teresa, beberapa karya utamanya adalah The Way of Perfection dan The Interior Castle.

\section{The Way of Perfection}

Buku ini mencatat keinginan Teresa dalam mengajarkan para pengikutnya untuk mencintai doa, sebagai cara untuk mendapatkan nilai kehidupan. ${ }^{50}$ Di dalam buku ini, ia menjelaskan bahwa tiga esensi dari kehidupan yang dipenuhi dengan doa adalah kasih yang timbal balik (mutual love), pengosongan diri dari benda-benda ciptaan, dan kerendahan hati yang sejati. ${ }^{51}$

Teresa mengajarkan bahwa kasih berhubungan dengan bagaimana seseorang memahami dan mengalami perbedaan dari dunia ini dengan kerajaan Allah dan antara benda ciptaan dengan penciptanya. Kasih ini dibangun dari kasih Tuhan yang terlebih dahulu diberikan kepada kita. Untuk dapat memiliki kasih di dalam doa, Teresa menjelaskan bahwa seseorang harus terlebih dahulu memahami bahwa Tuhan mengasihinya, sehingga ia juga memiliki alasan untuk mengasihi. ${ }^{52}$ Kasih Tuhan menjadi dasar dari kasih manusia, sekaligus menjadi satu-satunya upah yang diharapkan dari manusia. Dengan dasar inilah Teresa menjelaskan bahwa kasih ini muncul sebagai respons kepada Tuhan yang menyadarkan

\footnotetext{
${ }^{48} \mathrm{~A}$. Katherine Grieb, "Teresa of Ávila: The Interior Castle," Theology Today 62, no. 2 (Juli 2005): 232-233, https://doi.org/10.1177/004057360506200208.

${ }^{49}$ DePrinzio, "Your Word Pierced My Heart, and I Fell in Love," 3.

${ }^{50}$ E. Allison Peers, "Introduction," dalam The Way of Perfection, oleh Teresa of Avila, terj. E. Allison Peers (1946; repr., New York: Dover Publications, 2012), 13-20.

${ }^{51}$ Ibid.

${ }^{52}$ Ibid., 59-60.
} 
mereka bahwa dunia ini dan diri mereka sendiri tidak layak dicintai, jikalau bukan karena Tuhan mencintainya. ${ }^{53}$ Karena itu, kasih Tuhan membuat mereka tidak dapat mengasihi apa pun selain yang dikasihi oleh Tuhan. ${ }^{54}$

Di sisi yang lain, Teresa juga menekankan bahwa cinta di dalam doa adalah kesadaran bahwa Tuhan juga mengasihi orang-orang lain. ${ }^{55}$ Ketika seseorang mencintai Tuhan, maka kita juga seharusnya mencintai mereka yang dicintai Tuhan tanpa memedulikan kebaikan atau keburukan mereka. Doa seharusnya berhubungan erat dengan kasih: doa didasari dari kasih Tuhan atas manusia, dan menghasilkan respons kasih terhadap Tuhan dan sesama.

Mengenai pengosongan diri dari hal-hal duniawi, Teresa memaknainya sebagai sikap merengkuh Sang Pencipta itu sendiri, yang telah menanamkan kebajikan di dalam diri kita sedemikian rupa sehingga kita dimampukan untuk berkarya dengan memberi yang terbaik dari hari ke hari. ${ }^{56}$ Sikap asketis yang dimaksudkan selalu berhubungan dengan relasi antarmanusia. Melepaskan diri dari keinginan duniawi berarti membawa manusia sepenuhnya melayani Tuhan. Karena itu, bagi Teresa, tujuan dari pengosongan diri adalah membentuk satu komunitas cinta di dalam Tuhan dan segala pekerjaan baik di dalam pelayanan-Nya. ${ }^{57}$

\footnotetext{
${ }^{53}$ Teresa, The Way of Perfection, 33.

${ }^{54}$ Ibid., 34. Dalam bagian ini ia menggambarkan kecintaan pada Tuhan seperti menggali emas di dalam sebuah tambang, di mana usaha keras untuk mendapatkan sesuatu yang dicintai tidak akan dirasakan, melainkan justru menjadi suatu sukacita karena hal itu menjadi keinginan dari kehendak mereka (ibid).

${ }^{55}$ Ibid., 36.

${ }^{56}$ Ibid., 39.

${ }^{57}$ Kavanaugh, "Introduction," The Interior Castle, 13. Di dalam pengajarannya, Teresa menasihatkan para biarawati untuk tidak dikunjungi oleh orang-orang di luar biara pada masa-masa awal kehidupannya sebagai biarawati apabila kunjungan dari orang-orang tersebut dapat mengganggu hubungan mereka dengan Tuhan dan membawa mereka kepada kenyamanan yang membahayakan. Tujuan yang ingin dia capai bagi para biarawati adalah mencegah jiwa mencari hal-hal yang fana dan memfokuskan diri pada
}

Teresa juga sangat menekankan kerendahan hati di dalam doa dari para biarawati. Ia menasihati para biarawati untuk tidak membiarkan kesombongan mereka dicobai oleh Iblis. ${ }^{58}$ Teresa memberikan contoh teladan dari Kristus sendiri bahwa Ia pun menanggung penghinaan dari orang lain. Sebagai mempelai Kristus, orang percaya seharusnya menanggung hal yang sama, baik kehormatan yang Kristus dapatkan maupun hinaan yang Kristus tanggung.

Praktik melatih kerendahan hati ini menurut Teresa akan membawa manusia siap untuk dipimpin oleh Allah-untuk melayani dan memuji-Nya-dengan sukacita, dan dengan kesadaran bahwa mereka seharusnya masuk ke dalam neraka. Dengan demikian, di dalam mengejar kehidupan doa yang baik, seseorang akan dapat dengan setia mengusahakannya, di dalam kerendahan hati, tanpa memedulikan kesulitan yang mereka hadapi ataupun keinginan-keinginan yang harus mereka lepaskan. Menurut Teresa, inilah esensi yang ketiga dari doa, yakni kerendahan hati yang sejati. Ia berkata, "What I have understood of the matter is this: that the whole foundation of prayer must be laid in humility, and that the more a soul humbles itself in prayer, the more God lifts it up." 59

Tuhan (Teresa, The Way of Perfection, 41). Lih. juga Maureen Flynn, "The Spiritual Uses of Pain in Spanish Mysticism," Journal of The American Academy of Religion 64, no. 2 (1996): 260, https://www.jstor.org/stable/1466102. Maureen mengatakan bahwa mistisisme pada abad ke-16 menggunakan penderitaan (rasa sakit) untuk menjauhi keduniawian. Tidak hanya sampai di sana, menurutnya asketisme yang dilakukan pada zaman itu bukan sekadar menghindari keinginan daging, melainkan juga meninggalkan daging secara harafiah untuk dapat "naik" (transcend) kepada diri yang ilahi. Namun demikian, Teresa justru menunjukkan di banyak bagian The Way of Perfection bahwa kegiatan asketis difokuskan bukan untuk meninggalkan tubuh, tetapi melawan keinginan daging dan kenyamanan untuk tidak melakukan kehendak Allah.

${ }^{58}$ Ibid., 47-48, 50, 60.

${ }^{59}$ Teresa, The Spirit of S. Teresa, 170. 


\section{The Interior Castle}

Buku ini merupakan karya dari hasil perenungan Teresa setelah lima tahun mendalami pengalaman perjalanan mistiknya di dalam spiritualitas sampai di usianya yang ke-62, hingga dipandang mencapai sebuah sintesis terbaik dari konsep doanya. ${ }^{60}$ Dalam buku ini, Teresa menggambarkan jiwa manusia bagaikan sebuah kastil yang terbuat dari kristal. Dari dalam kastil ini terpancar keluar kasih Allah. ${ }^{61}$ Bagi Teresa, doa dan perenungan adalah pintu masuk kepada kastil ini. Doa merupakan proses perjalanan membawa jiwa manusia untuk memasuki ruangan demi ruangan yang ada, menuju ke dalam ruangan utama yang berada di bagian yang paling dalam, yakni ruangan tempat Tuhan hadir. ${ }^{62}$ Dalam menjalani proses memasuki ruanganruangan ini, Teresa mengatakan bahwa Kristuslah yang akan menjadi Pembimbing dan memberikan hikmat. ${ }^{63}$

Tujuan masuknya seseorang ke dalam jiwanya hingga masuk di ruangan yang terdalam adalah mencapai kesatuan dengan Tuhan-atau di dalam istilah Teresa mengalami pernikahan ilahi-dan mengalami perubahan menjadi "ilahi." Di dalam penggambarannya, Teresa menggambarkan perubahan manusia menjadi serupa dengan Tuhan adalah seperti ulat sutra yang mengalami metamorfosis. Penggambaran ini menjelaskan dasar dari solusi persoalan manusia untuk diubah menjadi serupa dengan gambar Allah melalui firman-Nya. Proses ini merupakan proses yang ganda dan bersifat dialektis, antara jiwa manusia dan firman Allah. ${ }^{64}$

Buku ini menggambarkan tujuh ruang ( $d w e l l-$ ing place atau mansion) hingga akhirnya jiwa

\footnotetext{
${ }^{60}$ Mary Margaret Anderson, "Thy Word in Me: on The Prayer of Union in St. Teresa of Avila's Interior Castle," Harvard Theological Review 99, no. 3 (Juli 2006): 334-336, https://doi.org/10.1017/S0017816006001271. Lihat juga Kavanaugh, "Introduction," The Interior Castle, 19.

${ }^{61}$ Grieb, "Teresa of Ávila: The Interior Castle," 230.

${ }^{62}$ Teresa, The Interior Castle, 35, 38.
}

dapat memiliki kesatuan dengan Tuhan. Tiga ruang yang pertama berbicara mengenai halhal yang dapat dicapai dengan usaha manusia dan bantuan umum dari anugerah. Empat ruang selanjutnya berbicara mengenai elemenelemen pasif ataupun mistis dari kehidupan spiritual. $^{65}$

Di dalam ruangan pertama yang disebut sebagai room of self-knowledge ini, seorang diajak untuk merefleksikan siapa dirinya di hadapan Allah yang agung. ${ }^{66}$ Teresa mengatakan bahwa pengetahuan akan diri sendiri ini tidak akan pernah sempurna tanpa pemahaman akan siapa Allah. Ketika melihat kemuliaan Allah, maka manusia baru akan dapat memahami kehinaannya. ${ }^{67}$ Pengetahuan akan diri yang hina ini, menurut Teresa, akan membawa kita kepada kerendahan hati yang sangat penting bagi proses memasuki ruanganruangan di dalam kastil ini. ${ }^{68}$

Dalam ruangan yang kedua, Teresa menekankan perlunya ketekunan untuk tetap berusaha memasuki ruangan yang selanjutnya dan ketahanan dari pencobaan Iblis yang dapat membawa seseorang ingin keluar dari kastil itu. ${ }^{69}$ Untuk melakukan itu, ia menawarkan sebuah cara, yakni mengingat kasih dan anugerah Allah. Setelah itu, seseorang harus terus mencoba untuk berdoa ketika Iblis mencobainya untuk berhenti berdoa.

Orang-orang yang tetap bertahan akan masuk ke dalam ruangan yang ketiga. Dalam ruangan ini, seseorang diajak oleh Teresa untuk waspada di dalam sebuah ketakutan untuk membantu diri tidak lengah terhadap keinginan duniawi yang dapat membawa pada

\footnotetext{
${ }^{63}$ Grieb, "Teresa of Ávila,” 232.

${ }^{64}$ Anderson, "Thy Word in Me," 333.

${ }^{65}$ Kavanaugh, "Introduction," The Interior Castle, 19.

${ }^{66}$ Teresa, The Interior Castle, 43.

${ }^{67}$ Ibid. Bdk. Grieb, "Teresa of Ávila,” 231.

${ }^{68}$ Teresa, The Interior Castle, 45.

${ }^{69}$ Ibid., 49-51, 53.
} 
kekeringan dalam doa. ${ }^{70}$ Untuk mencapai kewaspadaan ini dibutuhkan kerendahan hati, bahwa diri kita lemah dan sulit untuk melepaskan diri dari keduniawian.

Dalam ruangan keempat, Teresa mengatakan bahwa pengalaman supranatural dimulai. Di dalam bagian ini, Teresa menjelaskan mengenai ketenangan batin dan sukacita spiritual. Ketenangan batin diartikan olehnya sebagai pengalaman yang didapatkan ketika seseorang melakukan meditasi dan menyampaikan permohonan kepada Tuhan. ${ }^{71}$ Ketenangan batin terjadi di dalam keinginan untuk menyenangkan Tuhan dan menikmati kebersamaan dengan-Nya. Berbeda dengan itu, sukacita spiritual adalah posisi pasif seseorang ketika ia menerima sukacita yang dimulai dari kehadiran Tuhan yang dapat dirasakan oleh manusia. Sukacita spiritual ini adalah keadaan ketika Tuhan bekerja mendatangkan ketenangan dan kedamaian di dalam hati, karena manusia tidak dapat melakukannya dengan usahanya sendiri. ${ }^{72}$ Di ruangan ini, usaha manusia sudah tidak mampu untuk membawa diri semakin masuk ke dalam ruangan selanjutnya. Panggilan Tuhanlah yang membawa seseorang dapat melanjutkan perjalanannya.

${ }^{70}$ Ibid., 56-57, 59, 62.

${ }^{71}$ Ibid., 68-69.

${ }^{72}$ Anderson, "Thy Word in Me," 343.

${ }^{73}$ Ibid., 330.

${ }^{74}$ Teresa, The Interior Castle, 86 . Teresa di dalam bagian ini menggambarkan kondisi pasif dari pikiran, yang tidak dapat mencapai titik kesatuan dengan Tuhan melalui usahanya sendiri. Kondisi ini bukanlah kondisi tanpa pikiran seperti yang dikatakan oleh Groothuis (Bdk. Groothuis dan Geis, "Examining Contemplative Prayer,"14). Dimensi mistik yang ditekankan oleh Teresa dalam bagian ini adalah ketidakmampuan pikiran dalam memahami kesatuan dengan Allah. Hal ini dijelaskan oleh Howard. bahwa doa terkadang membawa manusia pada satu keadaan tidak dapat memahami karena Allah yang tak terbatas tidak dapat dipahami seutuhnya oleh manusia. Lih. Howard, "Is Thoughtless Prayer Really Christian?" 136.

${ }^{75}$ Teresa tidak mendefinisikan sukacita ini, namun ia memberikan gambaran bahwa sukacita ini seperti perasaan yang ada di luar tubuh dengan perasaan yang ada di dalam sumsum tulang (Teresa, The Interior Castle, 88).

${ }^{76}$ Anderson, "Thy Word in Me," 331. Bdk. Teresa, The Interior Castle, 98.
Ruangan kelima ini adalah ruangan yang penting untuk memahami konsep kesatuan dengan Tuhan. ${ }^{73}$ Teresa mengatakan bahwa dalam ruangan ini kondisi kesatuan dengan $\mathrm{Tu}-$ han serupa dengan keadaan bermimpi, namun tidak benar-benar bermimpi. Dalam definisinya, seseorang yang mencapai kesatuan dengan Tuhan tidak tertidur, namun di sisi keduniawian dan dirinya sendiri tertidur. Dengan demikian, seseorang hanya berfokus kepada hidup di dalam Tuhan. ${ }^{74}$ Kesatuan ini akan memberikan sukacita yang berbeda dari sukacita duniawi. ${ }^{75}$ Kesatuan dengan Tuhan ini ditandai dengan adanya kesatuan keinginan seseorang dengan keinginan Tuhan. ${ }^{76} \mathrm{Te}$ resa memberikan gambaran mengenai kesatuan ini bagaikan ulat sutra yang membungkus dirinya di dalam sebuah kepompong, kemudian ia mati, dan berkembang menjadi kupu-kupu yang indah. ${ }^{77}$

Di dalam ruangan keenam, Teresa menggambarkan relasi dengan Tuhan sudah mencapai titik pertunangan. ${ }^{78}$ Ia mengatakan bahwa di tahap ini, meskipun seseorang sudah sangat mendekati kesatuan dengan Tuhan, namun

${ }^{77}$ Ibid., 91. Penggambaran ini dipakai oleh Teresa untuk menggambarkan keadaan kesatuan di dalam Kristus bagi orang percaya di dalam doa (Anderson, "Thy Word in Me," 344). Ia mengatakan bahwa pertumbuhan ulat ini dari kecil menjadi besar menggambarkan seseorang yang didewasakan oleh Roh Kudus melalui pengajaran firman, buku-buku yang dibaca, maupun kejadian-kejadian dalam hidupnya. Setelah dewasa, ulat ini masuk ke dalam kepompong, yang menurut Teresa adalah Yesus (konsep ini diambil Teresa dari Kolose 3:2-3; Anderson, "Thy Word in Me," 346). Di dalam kepompong ini ulat tidak melakukan apa-apa, yang menggambarkan Tuhan yang bekerja mengubah manusia di dalam kesatuan denganNya (Teresa, The Interior Castle, 92). Untuk mengalami proses perubahan dari ulat menjadi kupu-kupu, maka diperlukan penanggalan kehendak pribadi dan kecintaan pada diri sendiri, meninggalkan keduniawian, mendapatkan pengampunan dosa (penance), dan berdoa hingga ia mengalami "kematian" dan pembaruan hidup (Anderson, "Thy Word in Me," 350).

${ }^{78}$ Ibid., 108. Bdk. Teresa, The Life of Teresa of Jesus, of the Order of Our Lady of Carmel, terj. David Lewis (1904; repr., Oklahoma: Veritatis Splendor, 2014), bab 9. Teresa di dalam doanya pernah mengalami pengalaman ketika ia 
tidak sedikit orang yang berhenti karena banyak cobaan dari dunia. ${ }^{79}$ Menurutnya, karena jiwa manusia itu lemah, maka solusi di dalam menghadapi cobaan-cobaan ini adalah berharap kepada Tuhan untuk membangkitkan jiwa. Kebangkitan jiwa ini didapatkan dari kecukupan yang Tuhan berikan melalui perkataan-Nya (locutions). Namun demikian, menurut Teresa, ada tiga perkataan yang sering kali membingungkan seseorang: perkataan dari Iblis, dari diri sendiri, dan dari Tuhan. ${ }^{80}$ Untuk membedakan perkataan ini, Teresa mengatakan bahwa tanda dari perkataan Tuhan adalah adanya kedamaian dalam hati. ${ }^{81}$ Dalam ruangan keenam ini, Teresa menjelaskan bahwa di dalam doa, tubuh mengalami banyak kelemahan dan kecacatan, sehingga hanya karya Tuhan yang dapat membawa seseorang mencapai tahap selanjutnya, ruangan ketujuh. Tidak ada satu praktik yang dapat dilakukan oleh manusia untuk dapat masuk ke dalam ruangan Tuhan. Tuhan membawa pendoa yang berdoa di dalam kehendak-Nya kepada alam supranatural dan sebuah kontemplasi yang sempurna. ${ }^{82}$

Di ruangan ketujuh, Teresa menggambarkan relasi manusia dengan Allah dalam pernikahan spiritual. Perbedaan antara kondisi pertunangan dengan kondisi pernikahan antara jiwa dengan Tuhan adalah bahwa di dalam

menyerahkan segala sesuatu di dalam hidupnya kepada Tuhan sebagai tunangannya.

${ }^{79}$ Teresa, The Interior Castle, 111.

${ }^{80}$ Ibid., 120. Berbeda dari apa yang dituduhkan oleh Groothuis (Groothuis, "Examining Contemplative Prayer," 20) bahwa doa mistik merupakan doa yang tidak waspada terhadap tipuan Iblis, Teresa justru menekankan bahwa Iblis dapat menipu manusia untuk menjauh dari doa yang benar.

${ }^{81}$ Teresa, The Interior Castle, 120-121.

${ }^{82}$ Ibid., 139, 148. Kondisi ini tidak berarti semata-mata tubuh diangkat menuju sesuatu yang transenden dan meninggalkan dunia ini, seperti yang dikatakan oleh Groothuis, "Examining Contemplative Prayer," 18. Kondisi yang digambarkan oleh Teresa adalah bahwa jiwa seseorang meninggalkan keduniawian dan keinginan daging sedemikian rupa sehingga ia hanya menginginkan hal-hal yang ilahi. pernikahan, seseorang tidak lagi dapat dipisahkan dengan Tuhan. ${ }^{83} \mathrm{Di}$ dalam pernikahan dengan Tuhan, Teresa menjelaskan bahwa seseorang menjadi lupa akan dirinya sendiri, dan apa yang diperhatikannya adalah apa yang Tuhan perhatikan, dan bahwa Tuhan menghiraukan orang yang berdoa. ${ }^{84}$ Apa yang terjadi selanjutnya adalah bahwa seseorang akan rela untuk menderita apabila itu yang dikehendaki Tuhan. Terlebih dari itu, Teresa bahkan mengatakan bahwa orang yang telah mengalami kesatuan dengan Tuhan akan dapat mengasihi orang-orang yang menyakiti mereka, karena ia melihat hal itu sebagai sesuatu yang diizinkan Tuhan terjadi untuk kebaikan. ${ }^{85}$

Dalam bagian yang terakhir, Teresa menjelaskan bahwa tujuan dari kesatuan dengan Allah adalah menguatkan jiwa di dalam kelemahannya untuk dapat meneladani Kristus di dalam penderitaan-Nya. Ia berkata, "This is the reason for prayer ... the purpose of this spiritual marriage: the birth always of good works, good works." ${ }^{86}$ Di dalam kesatuan dengan Allah yang Mahakuasa, orang-orang kudus akan memiliki ketekunan untuk melayani sesama yang mengalami kesusahan dan penderitaan. Menurut Gillian Ahlgren, seorang pakar tradisi mistik Kristen, tidak ada dalam tulisan Teresa yang secara khusus hanya tertarik pada kesalehan atau religiositas yang

${ }^{83}$ Ibid., 178-179. Teresa menggambarkan kesatuan dalam pertunangan dengan Tuhan bagaikan lilin yang disatukan, namun mudah untuk dipisahkan kembali, sedangkan pernikahan dengan Tuhan seperti tetes air hujan yang menyatu di dalam sungai, yang tidak dapat dipisahkan kembali.

${ }^{84}$ Ibid., 183, 188. Dalam bagian ini, Teresa juga menjelaskan bahwa meskipun melupakan akan diri sendiri, namun ini tidak berarti seseorang tidak memperhatikan hal-hal eksterior dari tubuhnya, seperti makan dan kebutuhan yang lain. Di dalam bagian yang berikutnya Teresa menjelaskan juga bahwa jiwa yang bersatu dengan Tuhan tidak akan lagi menginginkan hal-hal yang duniawi dan yang tidak sempurna, termasuk dosa-dosa.

${ }^{85}$ Ibid., 185.

${ }^{86}$ Ibid., 190-191. 
terputus dari dunia yang menderita, karena Teresa akan mengatakan bahwa itu adalah spiritualitas palsu. ${ }^{87}$ Pertumbuhan dan kedewasaan rohani seseorang diukur dari seberapa besar dan luas kapasitasnya dalam mengasihi sesama yang diwujudnyatakan dalam hidup sehari-hari melalui setiap pilihan, keputusan dan tindakan. Menurut paradigma Teresa, dari kepenuhan kesatuan jiwa seseorang dengan Allah akan dihasilkan potensi, vitalitas dan keteguhan mendalam untuk mengasihi orang lain sesulit apa pun tantangannya. Dalam bagian selanjutnya akan dipaparkan konsep doa menurut Jonathan Edwards yang dapat dikatakan mewakili teologi doa injili.

\section{Konsep Doa Injili Menurut Jonathan Edwards}

Pemikiran dan praktik doa Jonathan Edwards merupakan satu kesatuan yang tidak terpisahkan dari iman dan pemahaman teologinya yang dalam, terkhusus akan karakter Allah yang berdaulat, mulia, kudus, dan penuh kemurahan, serta penekanannya pada pengalaman penebusan Kristus dalam hidupnya. ${ }^{88}$ Baginya, perjumpaan dengan Tuhan dan pengalaman memahami Tuhan didasarkan pada pewahyuan transformatif yang berasal dari karya Kristus. Menjumpai Tuhan di dalam doa tidak akan dimungkinkan jika tidak mengalami karya penebusan Kristus. Pengalaman penebusan ini merupakan perubahan kelekatan emosional dari pengejaran akan kenikmatan dan menghindari penderitaan yang bersifat horisontal kepada sebuah orientasi yang baru, yakni afeksi yang radikal

\footnotetext{
${ }^{87}$ Gillian T.W. Ahlgren, "Wise action in a world of suffering and injustice: Teresa's vision for today," dalam Teresa of Avila: Mystical theology and spirituality in the Carmelite tradition, ed. Peter Tyler dan Edward Howells (London: Routledge, 2017), bab 9.

${ }^{88}$ Hannah, "Jonathan Edwards's Thoughts on Prayer," 84. Lihat juga Peter Beck, "Jonathan Edwards on Prayer and the Triune God," dalam Taking Hold of God: Reformed and Puritan Perspectives on Prayer, ed. Joel R. Beeke dan Brian G. Najapfour (Grand Rapids: Reformation Heritage, 2011), bab 10.

${ }^{89}$ Ibid., 85.
}

menuju kepada Tuhan yang bersifat vertikal. ${ }^{89}$

Edwards berujar bahwa doa adalah salah satu cara terbesar dan terbaik untuk memelihara natur manusia baru karena doa menumbuhkembangkan jiwa orang percaya. ${ }^{90}$ Doa adalah sarana untuk bertumbuh dalam pengenalan akan Allah, dan jalan menuju kehidupan persekutuan dengan-Nya. Bagi Edwards, doa lebih dari sekadar tugas atau kewajiban orang Kristen melainkan hak istimewa yang luar biasa dan bukti dari iman yang sejati. ${ }^{91}$

Jonathan Edwards mengalami pertobatan ketika membaca 1 Timotius 1:17. Ia berkata,

As I read the words, there came into my soul, and was as it were diffused through it, a sense of the glory of the Divine Being; a new sense, quite different from any thing I ever experienced before ... a new kind of apprehensions and ideas of Christ, and the work of redemption, and the glorious way of salvation by him ... a sweet sense of the glorious majesty and grace of God, that I know not how to express ... The appearance of everything was altered, there seemed to be, as it were, a calm, sweet cast, or appearance of divine glory. ${ }^{92}$

Pengalaman yang dirasakan oleh Edwards dimulai dari firman Tuhan yang meresap di dalam jiwa dan mengubahkan, sebuah perjumpaan dengan kemuliaan Allah serta pemahaman dan perasaan yang baru akan Kristus. Dari perjumpaan ini, Edward kemudian menjabarkan perasaannya sebagai perasaan yang

\footnotetext{
${ }^{90}$ Peter Beck, "Jonathan Edwards on Prayer and the Triune God," bab 10.

${ }^{91}$ Peter Beck, "The Voice of Faith: Jonathan Edwards's Theology of Prayer" (disertasi, Southern Baptist Theological Seminary, 2007), 18, 132.

${ }^{92}$ Jonathan Edwards, Letters and Personal Writings, vol. 16, The Works of Jonathan Edwards, ed. George S. Claghorn (New Haven: Yale University Press, 1998), 792793. Untuk selanjutnya akan disingkat WJE.
} 
"sweet, pleasant, charming, lovely, amiable, delightful, serene, calm, and still nature." ${ }^{93} \mathrm{Ba}-$ ginya, doa adalah sebuah tindakan mendekati kehadiran-Nya yang estetik dalam pribadi dan tindakan-Nya, sebuah realitas yang dijadikan nyata melalui hidup dari Tuhan sendiri yang diletakkan dalam jiwa orang-orang kudus. Di dalam teologi doa Edwards, Kristus adalah figur sentral yang melalui inkarnasi-Nya telah merestorasi hubungan manusia dengan Allah. Sama seperti Teresa, Edwards juga melihat keintiman orang percaya dengan Kristus sebagai sebuah pernikahan rohani, dengan berkata bahwa Kristus merendahkan diri cukup besar untuk menjadi sahabat (friend) dan pendamping (companion) orang percaya, untuk menyatukan jiwa mereka dengan-Nya dalam pernikahan rohani, cukup besar untuk mengambil natur mereka bagi-Nya, untuk menjadi salah satu dari mereka, supaya Ia menjadi satu dengan mereka. ${ }^{94}$

Dalam pemahaman Jonathan Edwards, terdapat lima konsep penting dari sebuah doa. ${ }^{95}$ Pertama, doa adalah sebuah persekutuan yang intim dan sebuah penyembahan, yang di dalamnya kita diizinkan dan diperintahkan untuk memasuki kehadiran dari pribadi yang paling mengagumkan dan estetik. Kedua, doa memiliki tujuan untuk menyatakan kemuliaan Tuhan melalui kesadaran dan kebergantungan diri kita bahwa Dia adalah sumber segala berkat. Ketiga, doa adalah keterbukaan Allah yang mengizinkan manusia untuk memasuki rencana-Nya di dalam membangun kerajaan-Nya. Keempat, doa adalah tindakan membawa ke hadapan Tuhan kebutuhan dan keinginan kita sebagai satu-satunya sumber pertolongan dan kebutuhan kita. Kelima, ketika Allah memberikan kerinduan untuk berdoa kepada umat-Nya, itu adalah bukti bahwa Allah ingin bekerja melalui mereka untuk melaksanakan kehendak-Nya.

\footnotetext{
${ }^{93}$ Jonathan Edwards, The "Miscellanies," WJE 13:163.

${ }^{94}$ Jonathan Edwards, "The Excellency of Christ," dalam WJE 19:566.

${ }^{95}$ Hannah, "Jonathan Edwards's Thoughts on Prayer,"
}

Perjumpaan dengan Tuhan tidak hanya berhenti sampai mengalami keindahan di dalam doa. Bagi Edwards, doa menghantarkan kita kepada kehidupan sehari-hari yang memuliakan Tuhan. Dia berkata, "Be more prayerful, more frequent and more earnest in your approaches to the throne of grace; and beside your set times of prayer, let your [heart] be frequently lifted up to God when you are about your daily affairs." ${ }^{96}$ Menurutnya, tidak ada cara lain orang percaya dapat memajukan pekerjaan Allah dan mengembangkan kerajaan Kristus selain dengan berdoa karena doa membangkitkan belas kasih kepada sesama di sekitar yang mengalami musibah dan penderitaan dan juga hasrat bagi kesejahteraan seluruh bangsa. ${ }^{97}$ Pada bagian selanjutnya akan dipaparkan kajian terhadap konsep doa Teresa dari Avila, yang kemudian akan dibandingkan dengan konsep doa Jonathan Edwards.

\section{Perbandingan Konsep Doa Teresa dari Avila dan Jonathan Edwards}

Konsep doa Teresa dari Avila tidak sama dengan konsep doa mistik yang didasari oleh pemahaman yang bersifat panteistik. Perjumpaan dengan pribadi Allah tidak dilakukan di dalam usaha manusia untuk mengosongkan pikiran, melainkan sebuah anugerah dari Allah ketika manusia melakukan pengosongan diri dari segala keinginan duniawi yang mengganggu ketenangan untuk berjumpa dengan-Nya. Konsep doa Teresa sangat dipengaruhi oleh konsep keberdosaan manusia dan anugerah Allah, sehingga baginya doa merupakan tindakan untuk mengalami perjumpaan dengan Tuhan Yesus dan firmanNya sebagai mediator antara pendoa dengan Allah. Dalam konsep doanya, Teresa menekankan kasih, kerendahan hati, dan penanggalan keduniawian dari manusia. Ketiga hal

\footnotetext{
${ }^{96}$ Jonathan Edwards, WJE 10:576.

${ }^{97}$ Jonathan Edwards, "Some Thoughts Concerning the Revival," dalam WJE 4:518, dan "An Humble Attempt," dalam WJE 5:340-341.
} 
ini yang menjadi esensi dari doa. Seorang pendoa seharusnya mengusahakan ketiga hal ini di dalam setiap doa yang mereka lakukan.

Teresa menggambarkan doa sebagai sebuah perjalanan ke dalam jiwa diri sendiri, yang digambarkan sebagai sebuah perjalanan masuk ke dalam sebuah istana kristal. Doa ini memiliki tujuan untuk mencapai ruangan terdalam dari istana tersebut, hingga akhirnya jiwa manusia dapat memiliki kesatuan melalui pernikahan spiritual dengan Tuhan. Pernikahan spiritual ini akan menghasilkan transformasi yang membuat kehendak pendoa tersebut menjadi sama seperti kehendak Tuhan. Doa yang seperti ini akan menghasilkan aktivitas yang menjangkau orang lain, yakni tindakan nyata untuk melakukan kehendak Tuhan. Kehendak yang ditransformasi membuat manusia melakukan apa yang Tuhan kehendaki, dan mencintai apa yang dicintai oleh Tuhan. Karena itu, doa mistik yang diajarkan oleh Teresa bukan berakhir pada pengasingan diri, melainkan pada hasrat dan kasih untuk melayani orang-orang di sekitar mereka.

Konsep doa Teresa dari Avila selaras dengan konsep doa dari Jonathan Edward. Bagi Edwards, doa adalah sebuah perjumpaan intim dengan Allah yang indah dan mengagumkan, sehingga membawa sebuah perasaan yang digambarkan oleh Teresa sebagai pernikahan spiritual. Perjumpaan ini dapat dialami di dalam Kristus sebagai mediator dan melalui firman Tuhan yang terinternalisasi di dalam jiwa manusia.

Konsep doa dari Edwards juga tidak berhenti di dalam diri sendiri atau pengasingan diri kepada Tuhan, melainkan menjadi sebuah kekuatan yang mendasari tindakan manusia di dunia untuk menyatakan kehendak Allah dan membangun kerajaan-Nya. Demikian juga Teresa melihat bahwa doa seharusnya mengerjakan transformasi di dalam diri manusia agar dapat melakukan kehendak Tuhan dan menyatakan kasih kepada dunia.

\section{KESIMPULAN}

Kajian terhadap konsep doa Teresa dari Avila berdasarkan konsep doa Jonathan Edwards memperlihatkan keterkaitan erat antara keduanya. Bagi Teresa maupun Edwards, doa adalah sebuah pengalaman keakraban dan kepenuhan jiwa bersama Allah yang keindahannya tak terkatakan, di dalam Kristus dan internalisasi firman sebagai mediatornya. Tidak hanya itu, konsep doa Teresa memberikan pemahaman yang lebih dalam mengenai bagaimana jiwa manusia dapat mengalami kesatuan dengan Allah secara mendalam, yang diibaratkannya sebagai percakapan akrab dengan sahabat yang kita tahu mengasihi kita. Meski demikian, pengalaman tinggal di dalam hadirat Allah tersebut bukan menjadi titik akhir. Pengalaman akan kasih Allah mengubahkan dan menggerakkan sang pendoa dengan hasrat yang besar untuk mengasihi dan melayani sesama sebagai upaya menghadirkan kerajaan Allah dan kehendak-Nya di tengah dunia. Dengan demikian konsep doa Teresa dari Avila dapat memperkaya spiritualitas tradisi doa injili, sehingga dapat dikembangkan dialog teologis antara konsep doa Teresa dari Avila dengan tradisi doa injili.

\section{PERNYATAAN PENULIS}

\section{Kontribusi dan Tanggung Jawab Penulis}

Penulis menyatakan telah memberikan kontribusi substansial untuk perancangan dan penulisan hasil penelitian. Penulis bertanggung jawab atas analisis, interpretasi dan diskusi hasil penelitian. Penulis telah membaca dan menyetujui naskah akhir.

\section{Konflik Kepentingan}

Penulis menyatakan tidak memiliki konflik kepentingan apa pun yang dapat memengaruhinya dalam penulisan artikel ini. 


\section{REFERENSI}

Ahlgren, Gillian T.W. "Wise action in a world of suffering and injustice: Teresa's vision for today." Dalam Teresa of Avila: Mystical theology and spirituality in the Carmelite tradition, diedit oleh Peter Tyler dan Edward Howells, bab 9. London: Routledge, 2017.

Anderson, Mary Margaret. "Thy Word in Me: on The Prayer of Union in St. Teresa of Avila's Interior Castle," Harvard Theological Review 99, no. 3 (Juli 2006): 329354. https://doi.org/10.1017/S0017816006 001271.

Beck, Peter. "The Voice of Faith: Jonathan Edwards's Theology of Prayer." Disertasi, Southern Baptist Theological Seminary, 2007.

-. "Jonathan Edwards on Prayer and the Triune God." Dalam Taking Hold of God: Reformed and Puritan Perspectives on Prayer, diedit oleh Joel R. Beeke dan Brian G. Najapfour, bab 10. Grand Rapids: Reformation Heritage, 2011.

Bloesch, Donald G. "Prayer and Mysticism (1) Two Types of Spirituality," Reformed Journal 26, no. 3 (Maret 1976): 23-26.

_. "Prayer and Mysticism (2) Divergent Views on Prayer." Reformed Journal 26, no. 4 (April 1976): 22-25.

-. "Prayer and Mysticism (3) Towards Renewed Evangelical Prayer," Reformed Journal 26, no. 5 (Mei-Juni 1976): 20-22.

Boa, Kenneth. Conformed to His Image. Grand Rapids: Zondervan, 2001.

Coe, John H. "The Controversy Over Contemplation and Contemplative Prayer: A Historical, Theological, and Biblical Resolution." Journal of Spiritual Formation and Soul Care 7, no. 1 (Mei 2014): 140-153. https://doi.org/10.1177/1939790 91400700112.

DePrinzio, Kevin M. "Your Word Pierced My Heart, and I Fell in Love: Teresa of Avila's Reading of Augustine of Hippo's Confessions." Disertasi, Catholic University of America, 2017.
Edwards, Jonathan. Letters and Personal Writings. Vol. 2, The Works of Jonathan Edwards. Diedit oleh George S. Claghorn. New Haven: Yale University Press, 1998.

- The Great Awakening. Vol. 4, The Works of Jonathan Edwards. Diedit oleh C.C. Goen. New Haven: Yale University Press, 1972.

- Apocalyptic Writings. Vol. 5, The Works of Jonathan Edwards. Diedit oleh Stephen J. Stein. New Haven: Yale University Press, 1977.

-. Sermons and Discourses, 1720-1723. Vol. 10, The Works of Jonathan Edwards. Diedit oleh Wilson H. Kimnach. New Haven: Yale University Press, 1992.

- The "Miscellanies". Vol. 13, The Works of Jonathan Edwards. Diedit oleh Thomas A. Schafer. New Haven: Yale University Press, 1994.

-. Sermons and Discourses, 1734-1738. Vol. 19, The Works of Jonathan Edwards. Diedit oleh M.X. Lesser. New Haven: Yale University Press, 2001.

Flynn, Maureen. "The Spiritual Uses of Pain in Spanish Mysticism," Journal of The American Academy Of Religion 64, no. 2 (1996): 257-278. https://www.jstor.org/ stable/1466102.

Gatta, Julia. "Mysticism and Incarnation," Sewanee Theological Review 36, no. 2 (1993): 259-263.

Grieb, A. Katherine. "Teresa of Ávila: The Interior Castle," Theology Today 62, no. 2 (Juli 2005): 230-234. https://doi.org/ $10.1177 / 004057360506200208$.

Groothuis, Douglas R. dan Sarah C. Geis. "Examining Contemplative Prayer," Bibliotheca Sacra 172, no. 685 (2015): 12-23.

Hannah, John, D. "Jonathan Edwards's Thoughts on Prayer," Bibliotheca Sacra 173, no. 689 (2016): 80-96.

Heer, Friedrich. Europaische Geistesgeschichte. Diedit oleh Johanna Heer dan Sigurd Paul Scheichl. Wien: Böhlau Verlag, 2004. 
Howard, Evan B. "Is Thoughtless Prayer Really Christian? A Biblical/Evangelical Response to Evagrius of Pontus," Journal of Spiritual Formation and Soul Care 7, no. 1 (2014): 118-139. https://doi.org/ 10.1177/193979091400700111.

Jensen, Peter J. "Prayer in Reformed Perspective," Reformed Theological Review 44, no. 3 (1985): 65-73.

Lovat, Alice Lady. The Life of Saint Teresa. London: Herbert \& Daniel, 1912.

Nouwen, Henri. The Prayer of the Heart. New York: Ballantine, 2003.

Nugent, Donald Christopher. "What Has Wittenberg to Do with Avila: Martin Luther and Saint Teresa," Journal of Ecumenical Studies 23, no. 4 (September 1986): 650-658.

Poloma, Margaret M. dan Lee, Matthew T. "From Prayer Activities to Receptive Prayer: Godly Love and The Knowledge that Surpasses Understanding," Journal of Psychology and Theology 39, no. 2 (Juni 2011): 143-154. https://doi.org/10.1177/ 009164711103900205.

Reininger, Gustave. "Centering Prayer and the Christian Contemplative Tradition," Sewanee Theological Review 40, no. 1 (1996): 29-45.

Serrán-Pagán y Fuentes, Cristóbal. "The Active Life and the Contemplative Life in St. John of the Cross: The Mixed Life in the Teresian Carmelite Tradition,"
Religions 11, no. 10 (2020): 509. https:// doi.org/10.3390/rel11100509.

Teresa of Avila. The Spirit of S. Teresa. London: Levey and Co., 1866.

- The Interior Castle. Classics of Western Spirituality. Diterjemahkan oleh Kieran Kavanaugh dan Otilio Rodriguez. New York: Paulist, 1979.

- The Way of Perfection. Diterjemahkan oleh E. Allison Peers. 1946. Reprint; New York: Dover Publications, 2012.

- The Life of Teresa of Jesus, of the Order of Our Lady of Carmel. Diterjemahkan oleh David Lewis. 1904. Reprint; Oklahoma: Veritatis Splendor, 2014.

Tyler, Peter. The Return to the Mystical: Ludwig Wittgenstein, Teresa of Avila and the Christian Mystical Tradition. London: Continuum, 2011.

Whitney, Donald S. "Defining The Boundaries of Evangelical Spirituality." Makalah yang disajikan pada pertemuan tahunan ke-53 Evangelical Theological Society, 15 November 2001.

Wilhoit, Jim. "Contemplative and Centering Prayer," Journal of Spiritual Formation and Soul Care 7, no. 1 (2014): 107-117. https://doi.org/10.1177/193979091400700 110.

Yungen, Ray. A Time of Departing: How Ancient Mystical Practices are Uniting Christians with the World's Religions. Ed. ke-2. Eureka: Lighthouse Trails, 2006. 